\title{
Sea turtle protection by communities in the Coast of Oaxaca, Mexico
}

\author{
Francesca Vannini ${ }^{1}$, Agustín Reyes Sánchez ${ }^{2}$, Galo Escamilla Martínez ${ }^{2}$, Constanza Santos López ${ }^{2}$, Ernesto Cruz ${ }^{2}$, \\ Pedro Franco ${ }^{2}$ and Héctor Pérez García ${ }^{2}$ \\ ${ }^{1}$ Carrettera Costera del Pacifico s/n, cp 71984, Puerto Escondido, Oaxaca, Mexico; francesca.vannini@gmail.com \\ ${ }^{2}$ Red de los Humedales, Puerto Escondido, Oaxaca, Mexico; unionhumedalesoaxaca@prodigy.com.mx
}

Received 3-XI-2010 Corrected 11-VII-2011 Accepted 29-VII-2011

\section{ABSTRACT}

The "Red de los Humedales de la Costa de Oaxaca" together with PROTUMAR, coordinate sea turtle conservation in five communitarian turtle campsites. Since 2005, efforts of nest protection have been executed for Olive Ridley (Lepidochelys olivacea), Black (Chelonia mydas) and Leatherback turtles (Dermochelys coriacea). Thousands of hatchlings have been released to the ocean each year. For the Olive Ridley sea turtle, in "La Ventanilla" (four seasons of work), 1003 nests have been protected, 95778 eggs have been incubated and a total of 59997 hatchlings have been liberated. In the campsite of "El Tomatal" 1110 nests, 96997 eggs and 52737 hatchlings. For "Los Naranjos" (since 2006), 553 nests, 53698 eggs, and 19512 hatchlings. For "Cerro Hermoso", 249 nests, 20633 eggs and 13934 hatchlings. Finally for "La Tuza de Monroy", an important nesting beach, 965 Olive Ridley nests, 85470 eggs and 62795 hatchings. For the Leatherback, the campsites that have protected more nests are "La Ventanilla" with a total of 45 nests and 516 hatchlings, "El Tomatal" with 19 nests and 435 hatchlings; for the Black sea turtle, "La Ventanilla" has registered 28 nests and 1239 hatchlings. This conservation work is highly significant because it is a communitarian initiative of people who in the past were egg collectors.

\section{KEY WORDS}

Marine turtles, Oaxaca, nests, hatchlings, liberation success.

\section{RESUMEN}

La Red de los Humedales de la Costa de Oaxaca, con el programa PROTUMAR, coordina el trabajo de conservación de las tortugas marinas en cinco campamentos tortugueros comunitarios. Desde el 2005 se protegen los nidos de tres especies de tortugas, tortuga golfina (Lepidochelys olivacea), prieta (Chelonia mydas) y laúd (Dermochelys coriacea) llegando a producir miles de crías que se liberan al mar cada año. En playa de Ventanilla, en las cuatro temporadas de trabajo se han protegido 1003 nidos de tortuga golfina, incubando 95778 huevos y liberando un total de 59997 crías, en El Tomatal 1110 nidos con 96997 huevos y 52737 crías, en Los Naranjos (que se involucró en la conservación en el 2006) 553 nidos, 53698 huevos y 19512 crías, en Cerro Hermoso 249 nidos con 20633 huevos y 13934 crías y La Tuza, playa de anidación muy importante, 965 nidos, 85470 huevos y 62795 crías. Para la tortuga laúd los campamentos que han protegido un mayor número de nidos son la Ventanilla con un total de 45 nidos y 516 crías, y el Tomatal con 19 nidos y 435 crías; para la tortuga prieta La Ventanilla ha registrado 28 nidos y 1239 crías. El trabajo realizado tiene mucha importancia al ser una iniciativa comunitaria de personas que antes se dedicaban al comercio de huevos y actualmente se dedican a su conservación.

\section{PALABRAS CLAVE}

Tortugas marinas, Oaxaca, nidos, crías, éxito de liberación.
Besides its biological (high biodiversity) and cultural importance (many different costumes are still living in this region), the coast of Oaxaca, Mexico, has been recognized for its importance in nesting sites for three species of sea turtle: olive ridley turtle (Lepidochelys olivacea), leatherback turtle (Dermochelys coriacea) and black turtle (Chelonia mydas).
For the leatherback turtle, considered as a critically endangered species by IUCN (2011), works of conservation and investigation in the state of Oaxaca were initiated in 1982 on the beaches of the national park of Chacahua, registering then 2841 females with nesting activities (Cruz \& Ruiz 1984). Approximately one decade later, Barra de la Cruz was recognized as an important nesting site, with 
1820 nests during the 1992/1993 season (Vásquez et al. 1994). Unfortunately, the increase in the efforts of protection of the leatherback, coincide with the collapse of the global population of this species. Sarti (2004) cites that the majority of the known populations have shown a drastic decline of more than $80 \%$ in less than 20 years and within the decade of 1980, it was estimated that the Mexican Pacific area accommodated $45 \%$ of the global population.

In past years, the olive ridley turtle, considered as endangered specie in vulnerable status (IUCN 2011), had a great economic importance that was attributed to the large concentration of individuals in front of nesting beaches, which presented minimal efforts of capturing. The commercial value of meat, eggs and skin, reached sufficient levels to support a wide market for sea turtle (Márquez et al. 1990). Due to this situation, the abundance in Mexico of this resource decreased towards the second half of the twentieth century, reaching dramatic levels in the 1980's. Because of this, regulatory measures have been recommended, for example, minimal capture size, adequate methods of fishing, quota of capture permitted, periods of closed season (Márquez et al. 1990), and protection of nests in hatcheries principally due to the heavy human depredation. In 1990, Mexican government prohibits marine turtles fishery in Mexican waters.

The black turtle, considered as an endangered specie (IUCN 2011), is not very common in the coast of Oaxaca, in fact in the pacific side of Mexico, the most important recognize nesting area is located in Michoacán (Colola and Maruata beaches) and Oaxaca is considered a less important nesting area (National Marine Fisheries Service 1998).

"Red de los Humedales de la Costa de Oaxaca" (RHCO) is a regional organization born in 2003 that unitify 22 communitarian groups that work in favor of the conservation of natural resources under an outline of community participation. Today, the RHCO operates different programs of work that protect species like mangroves and reptiles, and develop ecotourism in the coast. The organization operates the "Marine Turtle Protection Program" (PROTUMAR) in six beaches along the coast of Oaxaca with the principal objective of protecting marine turtle nests from the heavy human depredation in this area.

PROTUMAR arose as a regional program since the nesting season 2003-2004, with the participation of three communitarian campsites. Between 2007 and 2009 seven nesting beaches were integrated to the work of conservation along the coast of Oaxaca: La Ventanilla, in the municipality of Santa Maria Tonameca, El Tomatal, Los Naranjos and Barra de Navidad in Santa Maria Colotepec, Cerro Hermoso and El Venado in San Pedro Tututepec and La Tuza en Santiago Jamiltepec.

\section{Objectives}

- Protect the higher number of marine turtle's nests along six beaches in Oaxaca's coast.

- Produce the higher number of hatchlings from the protected nests.

\section{Area of Work}

The beaches protected until 2009 by the PROTUMAR program were: La Ventanilla, El Tomatal, Los Naranjos, Barra de Navidad (start in 2009), El Venado (start in 2009), Cerro Hermoso (stop in 2009) and La Tuza de Monroy. These beaches are located in the Coast of Oaxaca on the Pacific Ocean in the eastern side of Mexico. This work presents results of only five beaches where the patrolled zone covers a total of $35 \mathrm{~km}$ of beach (Fig.1).

\section{METHODOLOGY}

This paper contains data collected during four years from 2005 to 2009 . The protection work starts the 1st of August of every year and end the $30^{\text {th }}$ of April the following year. Hatcheries have a fenced area of about $8 \times 5$ meters and they are bolted about 20 meters from the line of the highest tide, therefore the ocean occasionally present very high tide that can flood the hatchery. In the beach of La Ventanilla the hatchery is covered by a sheet of shading net during all the season of protection and eggs incubation work.

Beach patrols generally begin from 21:00 until 02:00 depending on the number of nests founded on the beach. All nests that are found are also collected and taken to the hatchery where they are incubated again and protected until they hatch. Once they emergence, they are immediately liberated. Each nest is then revised after the liberation to value the liberation success.

The data taken of incubated nests were the following: date and hour of the collection, species, number of eggs, zone nest was found (near the shoreline, in the middle of the beach, near the vegetation), number of nests preyed on (this data is inconstantly collected), estimated hatch date to monitor the nests. Once the nest has hatched, a datasheet is filled out, where the revision of the nest and number of hatchlings produced is registered.

The data collected is analyzed in order to evaluate the protection activities. The following formulas is used to evaluate the liberation success:

$\%$ Liberation $=(\text { hatchlings liberated } / \text { total number of eggs })^{*} 100$ 


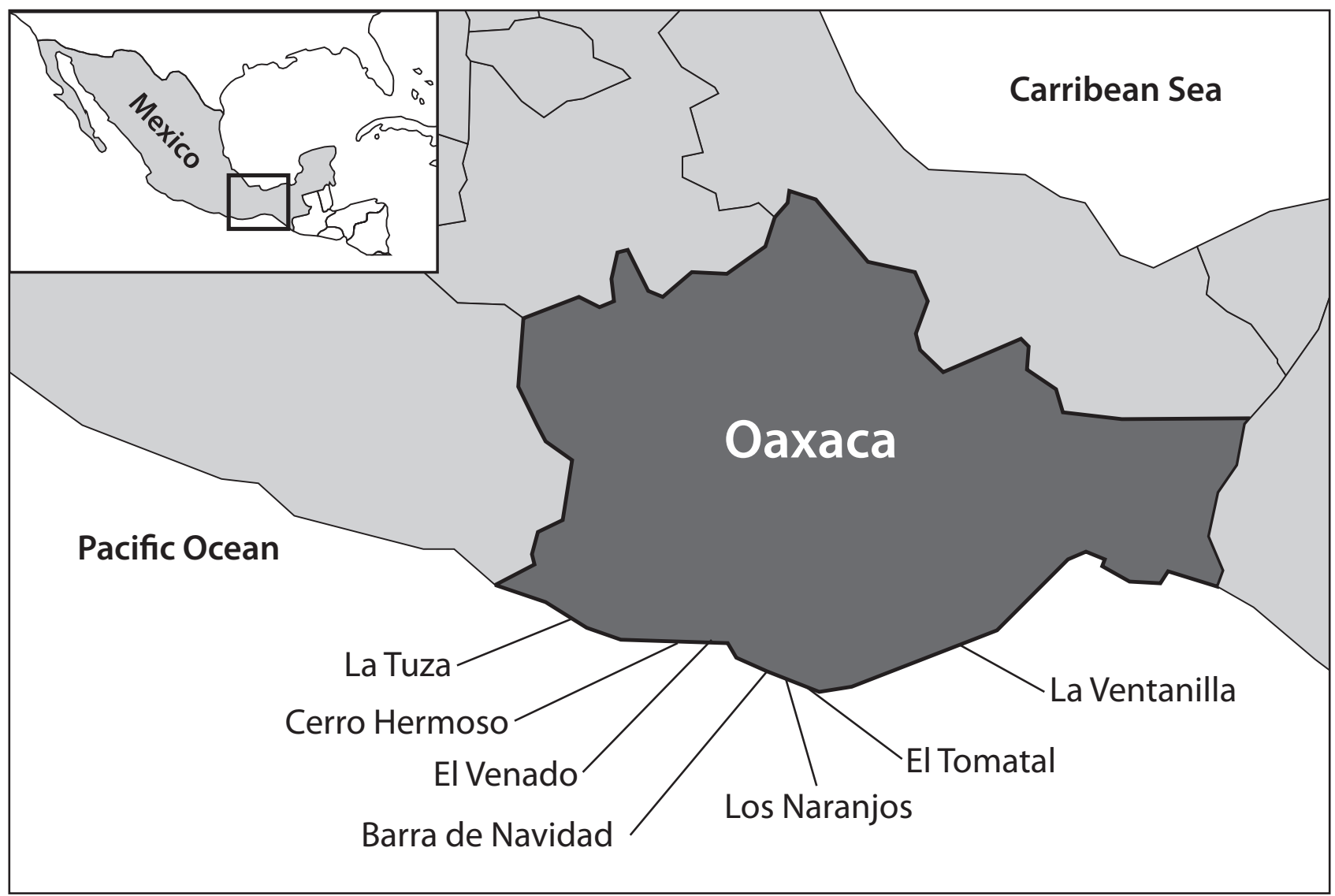

FIG. 1. Mexico, areas protected by PROTUMAR.

\section{TABLE 1}

General characteristics of surveyed beaches.

\begin{tabular}{|c|c|c|c|c|c|}
\hline Beach & $\begin{array}{l}\text { UTM Geog. } \\
\text { coordinates (start) }\end{array}$ & $\begin{array}{l}\text { UTM Geog. } \\
\text { coordinates (end) }\end{array}$ & $\begin{array}{c}\text { Total Length } \\
\text { patrolled (Km) }\end{array}$ & $\begin{array}{c}\text { Way of } \\
\text { monitoring }\end{array}$ & $\begin{array}{l}\text { Hatchery with } \\
\text { Shade }\end{array}$ \\
\hline La Ventanilla & $\begin{array}{c}755771,95 \mathrm{E} \\
1734897,67 \mathrm{~N}\end{array}$ & $\begin{array}{c}759990,01 \mathrm{E} \\
1733641,58 \mathrm{~N}\end{array}$ & From 4,5 to 7 & ATV (2008) & $40 \%$ \\
\hline El Tomatal & $\begin{array}{l}717555 \mathrm{E} \\
1747378 \mathrm{~N}\end{array}$ & $\begin{array}{l}712853 \mathrm{E} \\
1748449 \mathrm{~N}\end{array}$ & From 5,5 to 10 & Foot & No \\
\hline Los Naranjos & $\begin{array}{c}717555 \mathrm{E} \\
1747378 \mathrm{~N}\end{array}$ & $\begin{array}{c}712853 \mathrm{E} \\
1748449 \mathrm{~N}\end{array}$ & 5,0 & Foot & No \\
\hline Cerro Hermoso & $\begin{array}{l}660853 \mathrm{E} \\
1765074 \mathrm{~N}\end{array}$ & $\begin{array}{l}656686 \mathrm{E} \\
1766162 \mathrm{~N}\end{array}$ & 4,5 & Foot & No \\
\hline $\begin{array}{l}\text { La Tuza de } \\
\text { Monroy }\end{array}$ & $\begin{array}{c}621826 \mathrm{E} \\
1772623 \mathrm{~N}\end{array}$ & $\begin{array}{c}624333 \mathrm{E} \\
1770998 \mathrm{~N}\end{array}$ & 4,0 & Foot & No \\
\hline
\end{tabular}


It is not possible to calculate hatch success due to lack of needed data therefore were not considered in our calculations. The total number of protected nests, number of protected eggs and number of hatchlings released for species are calculated considering four seasons.

The communitarian work is not constant so data are not enough to calculate statistic parameters or make some kind of analysis. This is due to main actors that are partially involved in the work; in fact, people are still unable to sustain their families with the conservations activities.

During the season 2007/2008 in the community of El Tomatal, a group of biologist with ATV vehicle and a research equipment were help the protection work in the beach with people of the village.

\section{RESULTS AND DISCUSSION}

\section{Olive Ridley Turtle}

Results of olive ridley protection during the four seasons are resumed in Table 2. The beach of El Tomatal is the one that registered more protected nests, followed by La Tuza. In the 2007/2008 season people of El Tomatal monitored constantly the beach thanks to a group of researcher that realize the protection work and census with them. The number of protected nests was quite high thanks to the available technology (ATV vehicle) (Vannini et al. 2008).

Compared to other beaches of the Oaxaca's coast the number of total nests of the six beaches shows that this is not an "arribada" area, even that the olive ridley is the most common turtle in the area. Extraordinary concentration of females nests in the beach of Escobilla, Oaxaca, where thousand of nests are found every season (Pritchard 2002). Outside Mexico, like in Costa Rica are located important beaches that present 70,000 nesting females in a year like Playa Nancite, which is considered an "arribada" beach (Honarvar et al. 2008).

Results of protection eggs and liberation success of all beaches are showed in Table 3. The liberation success is very low but the compromise of people working to protect turtle's nests is appreciable: in fact, all nests left in the beach are poached. Ramírez (2002), declared that liberation success that is reported in L. olivacea, whether it be natural or unnatural (incubation corrals) conditions, goes from $65 \%$ to $85 \%$ approximately. Even that, result of liberation success increase year by year and this indicate that the handling is improving season next season.

The beach of La Ventanilla use a shade net to cover the hatchery but there is not a big difference of the liberation success $(54,4 \%)$ from the average of all beaches result; probably it is necessary temperatures study before shade the hatchery.

TABLE 2

Results of total number of olive ridley's (Lepidochelys olivacea) nests during the four seasons 2005/2009.

\begin{tabular}{lcccccccccc}
\hline \multicolumn{1}{c}{ Beach } & \multicolumn{2}{c}{$2005 / 2006$} & $2006 / 2007$ & $2007 / 2008$ & $2008 / 2009$ & \multicolumn{2}{c}{$\begin{array}{c}\text { Totals four } \\
\text { seasons }\end{array}$} \\
& $\begin{array}{l}\text { Tot } \\
\text { nests }\end{array}$ & $\begin{array}{c}\text { Prot } \\
\text { nests }\end{array}$ & $\begin{array}{c}\text { Tot } \\
\text { nests }\end{array}$ & $\begin{array}{c}\text { Prot } \\
\text { nests }\end{array}$ & $\begin{array}{c}\text { Tot } \\
\text { nests }\end{array}$ & $\begin{array}{c}\text { Prot } \\
\text { nests }\end{array}$ & $\begin{array}{c}\text { Tot } \\
\text { nests }\end{array}$ & $\begin{array}{c}\text { Prot } \\
\text { nests }\end{array}$ & $\begin{array}{c}\text { Tot } \\
\text { nests }\end{array}$ & $\begin{array}{c}\text { Prot } \\
\text { nests }\end{array}$ \\
\hline Ventanilla & 335 & 335 & 229 & 229 & 257 & 118 & 352 & 321 & 1173 & 1003 \\
El Tomatal & 227 & 227 & 317 & 317 & 446 & 446 & 376 & 142 & 1366 & 1110 \\
Los Naranjos & Nd & Nd & 366 & 366 & 126 & 126 & 111 & 82 & 603 & 553 \\
Cerro Hermoso & 82 & 82 & 89 & 89 & 135 & 135 & 154 & 39 & 460 & 249 \\
La Tuza de Monroy & 105 & 105 & 184 & 184 & 392 & 392 & 677 & 317 & 1358 & 965 \\
Totals & 749 & 749 & 1185 & 1185 & 1356 & 1356 & 1670 & 901 & 4960 & 3880
\end{tabular}


TABLE 3

Total number of olive ridley's (Lepidochelys olivacea) incubated eggs and liberated hatchlings during the four seasons 2005/2009.

\begin{tabular}{lccccccccccccccc}
\hline \multirow{2}{*}{ Season } & \multirow{2}{*}{ El Tomatal } & \multicolumn{2}{c}{ Ventanilla } & \multicolumn{2}{c}{ La Tuza de M. } & Los Naranjos & Cerro Hermoso & Total & $\begin{array}{c}\text { Lib. } \\
\text { succes }\end{array}$ \\
\hline & Eggs & Hatch & Eggs & Hatch & Eggs & Hatch & Eggs & Hatch & Eggs & Hatch & Eggs & Hatch & $(\%)$ \\
\hline $2005 / 2006$ & 32559 & 15481 & 21169 & 10853 & 0 & 0 & 9834 & 6516 & 7031 & 4788 & 70593 & 37638 & 53,3 \\
$2006 / 2007$ & 21989 & 16714 & 2933 & 1592 & 35701 & 8848 & 17067 & 13873 & 7637 & 4222 & 85287 & 45249 & 53,1 \\
$2007 / 2008$ & 10858 & 7037 & 33265 & 16335 & 10139 & 7224 & 29593 & 21495 & 3103 & 2387 & 86958 & 54778 & 63,0 \\
$2008 / 2009$ & 30412 & 20765 & 13213 & 9329 & 7858 & 344 & 28976 & 20911 & 2862 & 2537 & 83321 & 53886 & 64,7 \\
Totals & 95778 & 59997 & 70580 & 38409 & 53698 & 16416 & 85470 & 62795 & 20633 & 13934 & 326159 & 191551 & 58,7
\end{tabular}

\section{Leatherback turtle}

Leatherback turtle protection results are presented in Table 4. La Ventanilla is the beach with more nesting activities for this species, because of the availability of the ATV vehicle that make the protection more successfully. For the same reason, in El Tomatal during 2007/2008 season the protection of leatherback's nests present the real number of turtle activities and a higher number of protected nests with a good liberation success result (Vannini \& Rosales 2009).

The presence of leatherback turtle females is not so common in these six beaches compared to the index beaches of Oaxaca's coast like Barra de la Cruz, San Juan Chacahua and Cahuitan (Sarti et al. 2007).
Numbers of leatherback eggs and hatchling are showed in Table 5 . The liberation success is very low due to the difficulty of handling this kind of eggs.

The results of leatherback turtle protection are not satisfactory. Global liberation success for each season is quite low and only in 2007/2008 results (51\%) reaches the global result of index leatherback beaches of the Mexican Pacific, which on average is 44,5\% (Barragán et al. 2007). During that season El Tomatal presents the highest results because of the presence of a group of biologist that organize and supervise the work (Vannini \& Rosales 2009).

TABLE 4

Results of total number of leatherback's (Dermochelys coriacea) nests during the four seasons 2005/2009.

\begin{tabular}{|c|c|c|c|c|c|c|c|c|c|c|}
\hline \multirow[t]{2}{*}{ Beach } & \multicolumn{2}{|c|}{$2005 / 2006$} & \multicolumn{2}{|c|}{$2006 / 2007$} & \multicolumn{2}{|c|}{$2007 / 2008$} & \multicolumn{2}{|c|}{$2008 / 2009$} & \multicolumn{2}{|c|}{ Totals four seasons } \\
\hline & $\begin{array}{c}\text { Tot } \\
\text { nests }\end{array}$ & $\begin{array}{l}\text { Prot } \\
\text { nests }\end{array}$ & $\begin{array}{c}\text { Tot } \\
\text { nests }\end{array}$ & $\begin{array}{l}\text { Prot } \\
\text { nests }\end{array}$ & $\begin{array}{c}\text { Tot } \\
\text { nests }\end{array}$ & $\begin{array}{l}\text { Prot } \\
\text { nests }\end{array}$ & $\begin{array}{c}\text { Tot } \\
\text { nests }\end{array}$ & $\begin{array}{l}\text { Prot } \\
\text { nests }\end{array}$ & $\begin{array}{c}\text { Tot } \\
\text { nests }\end{array}$ & $\begin{array}{l}\text { Prot } \\
\text { nests }\end{array}$ \\
\hline Ventanilla & 23 & 23 & 3 & 3 & 6 & 5 & 15 & 14 & 47 & 45 \\
\hline El Tomatal & 6 & 6 & 1 & 1 & 14 & 11 & 1 & 0 & 22 & 18 \\
\hline Los Naranjos & nd & nd & 2 & 1 & 2 & 2 & 0 & 0 & 4 & 3 \\
\hline Cerro Hermoso & nd & nd & 1 & 1 & 0 & 0 & 0 & 0 & 1 & 1 \\
\hline La Tuza de Monroy & 5 & 5 & 1 & 1 & 1 & 1 & 9 & 1 & 16 & 8 \\
\hline Totals & 34 & 34 & 8 & 7 & 23 & 19 & 25 & 15 & 90 & 75 \\
\hline
\end{tabular}


TABLE 5

Total number of leatherback's (Dermochelys coriacea) incubated eggs and liberated hatchlings during the four seasons 2005/2009.

\begin{tabular}{ccccccccccccccc}
\hline Season & \multicolumn{2}{c}{ El Tomatal } & \multicolumn{2}{c}{ Ventanilla } & \multicolumn{2}{c}{ La Tuza de M. } & Los Naranjos & \multicolumn{2}{c}{$\begin{array}{c}\text { Cerro } \\
\text { Hermoso }\end{array}$} & Total & $\begin{array}{c}\text { Lib. } \\
\text { succes }\end{array}$ \\
\hline & Eggs & Hatch & Eggs & Hatch & Eggs & Hatch & Eggs & Hatch & Eggs & Hatch & Eggs & Hatch & $(\%)$ \\
\hline $2005 / 2006$ & 1652 & 222 & 287 & 82 & 262 & 0 & 0 & 0 & 0 & 0 & 2201 & 304 & 13,8 \\
$2006 / 2007$ & 252 & 57 & 68 & 0 & 48 & 35 & 72 & 0 & 52 & 0 & 492 & 92 & 18,7 \\
$2007 / 2008$ & 197 & 161 & 631 & 353 & 62 & 0 & 117 & 0 & 0 & 0 & 1007 & 514 & 51,0 \\
$2008 / 2009$ & 358 & 76 & 0 & 0 & 75 & 70 & 0 & 0 & 0 & 0 & 433 & 146 & 33,7 \\
Totals & 2459 & 516 & 986 & 435 & 447 & 105 & 189 & 0 & 52 & 0 & 4133 & 1056 & 26,6
\end{tabular}

\section{Black Turtle}

Protection results for black turtle are showed in Table 6 . This turtle is not so common along the worked area.

Black turtle eggs and hatchling results are showed in Table 7. Liberation success is also quite low compared to other protected beaches like Tierra Colorada, Guerrero, where it reaches $94 \%$ of liberation success (Ocampo et al. 2010, 2011).

\section{DISCUSSION}

\section{Difficulty of the work}

The efforts made by Red de los Humedales de la Costa de Oaxaca and the PROTUMAR program, have permitted achievement in the protection of a considerable number of nests thanks to the initiative of the communitarian groups that are worried about the conservation of natural resources and their rapid disappearance. The poaching of sea turtles eggs is the most important problem, which is why these worker groups start nests protection. All the people that now are working for the protection were involved in the poaching during the past.

Due to the organization of the communitarian fieldwork, data don't show the real total number of nests for each beach, the effort of the realized work is still not $100 \%$ (means every night during the protection work season) because the salaries they receive don't cover the effort needed to work all the nesting season. All nests they cannot protect remain in situ but we don't know their destiny. Despite this situation, these are the only data available for this beaches that cover a big area of the Coast of Oaxaca.

Turtles in the future do not depend only of their capability as species to recover their populations, but of the

TABLE 6

Results of total number of black turtle's (Chelonia mydas) nests during the four seasons 2005/2009.

\begin{tabular}{|c|c|c|c|c|c|c|c|c|c|c|}
\hline \multirow[t]{2}{*}{ Beach } & \multicolumn{2}{|c|}{$2005 / 2006$} & \multicolumn{2}{|c|}{$2006 / 2007$} & \multicolumn{2}{|c|}{$2007 / 2008$} & \multicolumn{2}{|c|}{$2008 / 2009$} & \multicolumn{2}{|c|}{ Totals four seasons } \\
\hline & $\begin{array}{c}\text { Tot } \\
\text { nests }\end{array}$ & $\begin{array}{l}\text { Prot } \\
\text { nests }\end{array}$ & $\begin{array}{c}\text { Tot } \\
\text { nests }\end{array}$ & $\begin{array}{l}\text { Prot } \\
\text { nests }\end{array}$ & $\begin{array}{c}\text { Tot } \\
\text { nests }\end{array}$ & $\begin{array}{l}\text { Prot } \\
\text { nests }\end{array}$ & $\begin{array}{c}\text { Tot } \\
\text { nests }\end{array}$ & $\begin{array}{c}\text { Prot } \\
\text { nests }\end{array}$ & $\begin{array}{c}\text { Tot } \\
\text { nests }\end{array}$ & $\begin{array}{l}\text { Prot } \\
\text { nests }\end{array}$ \\
\hline Ventanilla & 2 & 2 & 8 & 8 & 2 & 2 & 16 & 16 & 28 & 28 \\
\hline El Tomatal & 2 & 2 & 0 & 0 & 2 & 2 & 0 & 0 & 3 & 3 \\
\hline Los Naranjos & nd & nd & 2 & 2 & 0 & 0 & 0 & 0 & 2 & 2 \\
\hline Cerro Hermoso & 1 & 1 & 0 & 0 & 0 & 0 & 1 & 1 & 2 & 2 \\
\hline La Tuza de Monroy & 2 & 2 & 1 & 1 & 2 & 2 & 3 & 3 & 8 & 8 \\
\hline Totals & 7 & 7 & 11 & 11 & 6 & 6 & 20 & 20 & 43 & 43 \\
\hline
\end{tabular}


TABLE 7

Total number of black turtle's (Chelonia mydas) incubated eggs and liberated hatchlings during the four seasons 2005/2009.

\begin{tabular}{lcccccccccccccc}
\hline \multirow{2}{*}{ Season } & \multicolumn{2}{c}{ El Tomatal } & \multicolumn{2}{c}{ Ventanilla } & \multicolumn{2}{c}{ La Tuza de M. } & Los Naranjos & Cerro Hermoso & Total & $\begin{array}{c}\text { Lib. } \\
\text { succes }\end{array}$ \\
\hline & Eggs & Hatch & Eggs & Hatch & Eggs & Hatch & Eggs & Hatch & Eggs & Hatch & Eggs & Hatch & $(\%)$ \\
\hline $2005 / 2006$ & 186 & 147 & 202 & 70 & 184 & 156 & 0 & 0 & 107 & 0 & 679 & 373 & 54,9 \\
$2006 / 2007$ & 477 & 250 & 78 & 68 & 0 & 0 & 188 & 0 & 0 & 0 & 743 & 318 & 42,8 \\
$2007 / 2008$ & 162 & 0 & 191 & 142 & 110 & 0 & 0 & 0 & 0 & 0 & 463 & 142 & 30,7 \\
$2008 / 2009$ & 1068 & 842 & 201 & 130 & 0 & 0 & 0 & 0 & 59 & 38 & 1328 & 1010 & 76,1 \\
Totals & 1893 & 1239 & 672 & 410 & 294 & 156 & 188 & 0 & 166 & 38 & 3213 & 1843 & 57,4
\end{tabular}

activities than in favor of them be accomplished by man and the work conducted by the communities in Oaxaca is an example.

\section{Conclusions}

- It is important to continue and increase the work of nest protection for sea turtles in this area.

- More training and a better management of leatherback turtle nests are needed in order to increase the recruitment of this species.

- It is priority to do more studies in order to understand the parameters that influence in the recruitment of hatchlings.

\section{REFERENCES}

Barragán, A., E. Ocampo, D. Garcia, L. Sarti \& P. Dutton. 2007. Conservación de la tortuga laúd (Dermochelys coriacea) en las playas índices del Pacifico mexicano. Temporada 2006/2007. Informe técnico final. Dirección de especies prioritarias para la conservación, CONANP. Kutzari, Para el estudio y la conservación de las tortuga marinas. Mexico D.F., Mexico.

Cruz, E. \& G. Ruiz 1984. La preservación de la tortuga marina. Revista Ciencia y Desarrollo 56:66-79

Honarvar S., M.P. O-Connor \& J.R. Spotila. 2008. Density-dependent effects on hatchng success of the olive ridley turtle, Lepidochelys olivacea. Population ecology 157: 21-230

IUCN 2011. IUCN Red List of Threatened Species. (http://www. iucnredlist.org; downloaded 11 July, 2011)

National Marine Fisheries Service and U.S. Fish and Wildlife Service. 1998. Recovery Plan for U.S. Pacific Population of the East Pacific Green Turtle (Chelonia mydas). National Marine Fisheries Service, Silver Spring. MD. Maryland, USA.
Márquez, R., J. Vasconcelos \& C. Peñaflores 1990. XXV Años de Investigación, conservación y protección de la tortuga marina. Secretaría de Pesca, Instituto Nacional de la Pesca. D.F., Mexico.

Pritchard P.C.H. 2002. Global Status of Sea Turtles: an owerview, document INF-001 prepared for Inter-American Convention for the Protection and Conservation of Sea Turtles, First Conference of the Parties (COP1/AC), First part 6-8 Agust, 2002, San José, Costa Rica.

Ramírez, M. E. B. 2002. Éxito de Eclosión en nidos de Lepidochelys olivacea en el vivero de Playa Toluca, Departamento de La Libertad, El Salvador. Tesis de Licenciatura.Universidad de El Salvador. San Salvador, El Salvador.

Ocampo E., Q. I. Gómez-Padrón \& V. O. Vargas. 2010. Conservación de la población de tortugas marinas, con énfasis en tortuga laúd (Dermochelys coriacea) en el Santuario de Tierra Colorada, Gro. Temporada 2009-2010. Informe Técnico Final. Dirección de Especies Prioritarias para la Conservación, CONANP. Kutzari Asoc. para el Estudio y Conservación de las Tortugas Marinas A.C., D.F., México.

Ocampo E., F. Vannini \& J.L.G. Miranda. 2011. Conservación de la población de tortugas marinas, con énfasis en tortuga laúd (Dermochelys coriacea) en el Santuario de Tierra Colorada, Gro. Temporada 2010- 2011. Informe final de resultados. Informe Técnico Final. Dirección de Especies Prioritarias para la Conservación, CONANP. Kutzari Asoc. para el Estudio y Conservación de las Tortugas Marinas A.C., D.F., México.

Sarti, L. 2004. Situación actual de la tortuga laúd (Dermochelys coriacea) en el Pacífico mexicano y medidas para su recuperación y conservación. Secretaría de Medio Ambiente y Recursos Naturales. D.F., México.

Sarti M.L., A.R. Barragan, D.G. Muñoz, N. Garcia, P. Huerta \& F. Vargas. 2007. Conservation Biology of the Leatherback Turtle in the Mexican Pacific. Chelonian Conservation and Biology 6:70-78 
Vannini, F., C. Mancusi \& R.Silvestri. 2008. Nesting of Lepidochelys olivacea, Dermochelys coriacea and Chelonia mydas agassizii in 2007/2008 in Tomatal, Oaxaca, Mexico. Biologia Marina Mediterranea 15:362-363

Vannini F. \& P.A.J. Rosales. 2009. Leatherback nesting in Tomatal, Oaxaca, Mexico in 2007/2008. Marine Turtle Newsletter 126:15-16
Vásquez, G, A. Olivera \& M. López. 1994. Temporada de anidación 1992-1993 de las tortugas laúd (Dermochelys coriacea), golfina (Lepidochelys olivacea) y prieta (Chelonia agassizii) en el campamento tortuguero de Barra de la Cruz, Oaxaca. Universidad Autónoma Benito Juárez de Oaxaca. Oaxaca. México. 